\title{
Model E-Genre Based Learning dalam Pembimbingan Penulisan Proposal Skripsi Mahasiswa Pendidikan Bahasa Indonesia FKIP Universitas Bengkulu
}

\author{
Arono $^{1}$, Syahriman ${ }^{2}$, Nadrah $^{3}$ \\ ${ }^{1,2}$ Universitas Bengkulu, Bengkulu, Indonesia \\ ${ }^{3}$ Institut Agama Islam Negeri Bengkulu, Bengkulu, Indonesia \\ 1arono@unib.ac.id
}

Abstract : The current pandemic condition allows a thesis proposal supervisor to apply online tutoring optimally. However, in its reality not all supervisors were always able to implement online mentoring both using synchronously and asynchronously methods, such as e-learning, google drive, WhatsApp, zoom meetings, and google meet. This study aimed to describe the development of students' thesis proposal writings through e-genre based learning model used in mentoring thesis proposals for students of JPBS FKIP Indonesian Language Education Study Program, University of Bengkulu, in Semester VIII. This research used a qualitative approach by applying a case study method. The results showed that e-genre based learning model was effective in improving the quality of students' proposal writings up to (77\%) in completing their proposals in each part of the proposal, in the introduction, literature review, and research methodology, in which the average increase reached $24 \%$. The most dominant thing there was an increase in students' proposal writings, namely the stage of writing texts independently and collectively, but the context building stage and text modeling greatly determined the success of students in writing proposals at the next stage of model development both synchronously and asynchronously. Therefore, a good e-genre based learning model could be an effective alternative in improving student writing skills, especially in online thesis proposal tutoring.

Keywords: e-genre based learning model, writing guidance, research proposal

Abstrak : Kondisi pandemi saat ini memungkinkan dosen pembimbing proposal skripsi untuk memaksimalkan pembimbingan secara daring. Namun, dalam kenyataannya tidak semua dosen pembimbing mampu memaksimalkan pembimbingan melalui daring baik secara sinkronus maupun asinkronus, seperti e-learning, google drive, whatsApp, zoom meeting, dan google meet. Penelitian ini bertujuan menggambarkan peningkatan penulisan proposal skripsi mahasiswa melalui model e-genre based learning dalam pembimbingan proposal skripsi mahasiswa Program Studi Pendidikan Bahasa Indonesia JPBS FKIP Universitas Bengkulu Semester VIII. Penelitian ini menggunakan pendekatan kualitatif dengan metode studi kasus. Hasil penelitian menunjukkan bahwa model e-genre based learning telah mampu meningkatkan kualitas proposal menulis mahasiswa dengan baik $(77 \%)$ dalam penyelesaian proposalnya pada setiap bagian 
proposalnya, baik pada bagian pendahuluan, kajian pustaka, maupun metodologi penelitian, yaitu rata-rata peningkatannya sebesar $24 \%$. Hal yang paling dominan terjadi peningkatan dalam menulis proposal mahasiswa ini, yaitu tahap penulisan teks secara mandiri dan secara bersama-sama, tetapi tahap pembanguan konteks dan pemodelan teks sangat menentukan keberhasilan mahasiswa dalam menulis proposal pada tahap pengembangan model berikutnya baik secara sinkronus maupun asinkronus. Oleh karena itu, model e-genre based learning yang baik dapat menjadi salah satu alternatif yang efektif dalam meningkatkan keterampilan menulis mahasiswa khususnya dalam pembimbingan proposal skripsi secara daring

Kata Kunci : model e-genre based learning, pembimbingan penulisan, proposal penelitian.

\section{Pendahuluan}

Berbagai model pembimbingan saat ini dilakukan oleh dosen pembimbing dalam membimbing penulisan proposal skripsi. Hal itu dilakukan dalam menyiasati permasalahan pandemi saat ini. Kondisi pandemi ini akan menjadikan model permanen ke depan dalam pembimbingaan proposal skripsi mahasiswa. Model pembimbingan ini disebut dengan model bauran. Model bauran ini menggabungkan model pembimbingan online dengan tatap muka atau langsung sehingga siswa mampu belajar secara mandiri (Yulianti \& Saputra, 2020). Hal ini bisa dilakukan dengan sinkronus dan asinkronus.

Hal yang paling tepat dilakukan saat ini dengan model daring. Hal itu dilakukan lebih memudahkan dan meningkatkan intensitas bimbingan lebih baik. Secara daring mampu mengefektifkan waktu dan biaya mahasiswa dalam penyusunan proposal penelitian. Jika memang harus tatap muka, mahasiswa sudah tuntas dalam pembimbingan daring. Artinya mahasiswa tinggal pembimbingan kelengkapan administrasi akan seminar proposal saja kemudian dilakukan tatap muka. Yang lebih memprihatinkan ada anggapan jika belum bimbingan tatap muka dianggap belum bimbingan oleh pembimbing. Padahal pembelajaran tidak hanya tatap muka melainkan bisa dilakukan dengan daring atau e-learning baik secara sinkronus maupun asinkronus. Hal ini dikemukakan oleh Syahruddin (2020) dan Iswanto \& Hidayat (2020) bahwa pembelajaran tidak hanya tatap muka, melainkan bisa melalui $e$ learning. Kemajuan teknologi saat ini memungkinkan setiap pembimbing dan mahasiswa memanfaatkannya.

Proposal skripsi merupakan salah satu syarat yang harus dipenuhi dan diselesaikan dalam penyelesaian studi sarjana. Sebagai salah satu mata kuliah yang terdiri atas 4 SKS, mata kuliah ini diberikan di semester akhir/semester VIII sehingga sangat menentukan keberhasilan atau penyelesaian studi mahasiswa jika pembimbingannya lancar, baik, dan sistematis. Namun, dalam kenyataannya masih terdapat mahasiswa yang tidak tepat dalam penyelesaian studinya karena pembimbingan penulisan proposal penelitian melebihi waktu yang telah ditentukan.

Banyak faktor yang memengaruhi keterlambatan mahasiswa dalam menulis proposal penelitian, diantaranya keterbatasan kemampuan mahasiswa dalam memahami dan menyelesaikan setiap koreksi yang disarankan oleh pembimbing, ketersediaan waktu yang diberikan oleh 
dosen dalam bimbingan, pemanfaatan teknologi oleh mahasiswa dan dosen dalam bimbingan, dan berkesinambungannya setiap revisi dalam proposal skripsi yang diberikan dengan yang diperbaiki/direvisi. Seperti yang dikemukakan oleh Siswanto \& Sampurno (2015) faktor yang menghambat dalam menulis proposal skripsi diantaranya, mahasiswa kesulitan dalam menemukan permasalahan topik penelitian, mahasiswa lebih fokus laporan KKN PPL, mengulang banyak mata kuliah, tidak rutin bimbingan dengan dosen, dan kesulitan dalam menulis karya tulis ilmiah. Kesulitan inilah dapat diminimalisasi dengan menerapkan model genre base learning.

Model e-genre based learning merupakan proses sosial dalam hal ini mahasiswa dan dosen yang berorientasi kepada tujuan yang dicapai secara bertahap dalam hal ini menulis proposal. Genre sebagai proses sosial dalam berkomunikasi dengan menggunakan teks untuk melakukan kegiatan menulis. Model e-genre based learning memiliki empat tahap, yaitu pembangunan konteks, pemodelan teks, pembuatan teks secara bersama-sama, tahap pembuatan teks secara mandiri (Feez, 1998; Bhatia, 2004; Bawarshi \& Reiff, 2010; Rose \& Martin, 2012; Burgos, 2017). Model ini dilakaksanakan secara daring dengan mengikuti keempat tahapan tersebut.

Proposal penelitian merupakan suatu rancangan tertulis karya ilmiah dengan sistematika tertentu. Proposal penelitian pada umumnya terdiri atas pendahuluan, kajian teori, dan metodologi penelitian. Bagian pendahuluan mencakup menentukan alasan topik sentral, meninjau penelitian sebelumnya, menyatakan gap, menentukan rumusan masalah penelitian, dan menentukan tujuan penelitian. Kajian pustaka merupakan sintesis dari sumber bacaan penulis untuk berargumen dalam tulisannya sehingga dalam kajian pustaka harus memuat teori terbaru yang berhubungan dengan topik yang diteliti dan mengacu pada ulasan artikel jurnal, buku, dan sumber ilmiah lainnya baik secara integral maupun nonintegral. Metodologi penelitian merupakan suatu alat yang akan digunakan dalam pengumpulan data, yaitu alasan menggunakan metode, teknik pengumpulan data, teknik analisis data, dan keabsahan data. (Swales, 1990 \& 2004; Lim's, 2006; Arsyad \& Arono, 2016 \& 2019).

Beberapa penelitian mengenai model genre based learning diantaranya dalam penulisan karya ilmiah, yaitu Arono \& Arsyad (2019) menemukan bahwa pendampingan model genre dalam penulisan draf artikel jurnal penelitian bidang humaniora pada dosen efektif meningkatkan kemampuan dosen dalam menulis artikel untuk dipublikasikan pada jurnal internasional bereputasi. Selain itu, penelitian model genre based learning dalam pengajaran bahasa dapat meningkatkan keterampilan menulis siswa, diantaranya menulis teks deskripsi (Mahanani, et al., 2018; Khasanah, 2018; Dewantara, et al., 2019; Resmisari, 2020). Secara umum peneitian ini dilakukan dengan tatap muka di ruang kelas dan masih sedikit dilakukan dalam tatap maya atau melalui daring baik sinkronus mauoun asinkronus.

Penelitian dalam pembimbingan penulisan proposal penelitian telah dilakukan oleh Iswari et al. (2017) dalam bentuk pelatihan pada guru-guru sehingga mampu menulis proposal PTK. Keberhasilan penulisan proposal itu bisa 186 
dilihat dari survei dan aplikasi yang dilakukan terhadap pembimbingan dan pelayanan dosen kepada mahasiswa, yaitu pelayanan pembimbingan yang diberikan cukup tinggi sehingga menentukan keberhasilan mahasiswa dalam menulis skripsi begitu juga dengan aplikasi pembimbingannya (Widagdo, et al., 2010; Hariyati, 2012; Nursalim, 2018; Kurniawan \& Bondowoso, 2020).

Berdasarkan kedua permasalahan di atas, yaitu model e-genre based learning dan pembimbingan penulisan proposal dapat meningkatkan keterampilan siswa atau peserta pembimbingan penulisan secara umum. Oleh karena itu, penulis dalam penelitian bertujuan mendeskripsikan kegiatan pembimbingan penulisan proposal skripsi melalui model genre based learning secara daring. Hal itu diharapkan menjadi salah satu pilihan temuan pembimbingan penulisan proposal skripsi mahasiswa yang efektif saat ini.

\section{Metode Penelitian}

Penelitian ini menggunakan pendekatan kualitatif dengan metode studi kasus. Secara kualitatif penelitian ini menggambarkan secara almiah dengan narasi verbal tahapan hasil pembimbingan dengan menggunakan genre based learning secara daring baik sinkronus maupun asinkronus. Perihal yang dikaji berhubungan dengan permasalahan pembimbingan, konteks daring, isu dalam penulisan proposal penelitian, dan pelajaran yang dapat diambil dari kasus pembimbingan (McMillan, 2008).

Studi kasus di sini maksudnya peneliti hanya mengungkapkan proses pembimbingan yang dilakukan oleh delapan mahasiswa. Delapan mahasiswa di sini artinya subjeknya yang sempit dibatasi dengan kerangka konteks tertentu dan pemecahan masalah yang aktual (Arikunto, 1980; Creswell, 2008). Penelitian secara intensif ini di bawah pembimbingan peneliti secara penuh dilakukan melalui daring, yaitu menggunakan zoom metting, video call whatshap group, dan google meet untuk melakukan tatap maya atau sinkronus; google drive, whatshapp grup, dan $e$ learning untuk melakukan diskusi, pengiriman revisi atau perbaikan, dan bahan-bahan materi proposal seperti panduan penulisan proposal, sumber-sumber pustaka atau bacaan yang relevan, dan review artikel jurnal penelitian secara asinkronus.

Teknik pengumpulan data dilakukan dengan penugasan melalui tautan daring setiap revisi proposal yang telah dikerjakan melalui google drive dan e-learning. Selain itu, wawancara terbuka. Wawancara dilakukan untuk mengungkapkan dan menggali permasalahan dalam pembimbingan yang dilakukan. Adapaun teknik analisis datanya, yaitu proposal yang telah direvisi sampai tiga kali dianalisis dan direvisi sesuai dengan tingkat perbaikannya. Setelah itu, merekapitulasi kecenderungan perbaikan yang ditemui, dan merumuskan dalam bentuk tabulasi dalam mengidentifikasi permasalahan revisi proposal yang dilakukan oleh mahasiswa dengan mengikuti model genre based learning secara daring sinkronus dan asinkronus. Adapun ketentuan peningkatan menulis proposal skripsi sebagai penentuan skala persentasenya, yaitu 1-20 (rendah), 21-40 (kurang), 41-60 (cukup), 61-80 (baik), dan 80-100 (sangat baik). Pesentase ini digunakan sebagai standar keberhasilan 
dalam menulis proposal skripsi, yaitu data kualitatif yang dikuantifikasikan.

\section{Hasil dan Pembahasan}

Pembimbingan model e-genre based learning dilakukan selama satu bulan, 15 Maret sampai dengan 12 April dengan ketentuan setiap tahap dilakukan satu kali pertemuan sinkronus dan secara asinkronus sesuai dengan permasalahan masing-masing mahasiswa. Adapun model e-genre based learning yang dilakukan yaitu pembangunan konteks, pemodelan teks, pembuatan teks secara bersama-sama, tahap pembuatan teks secara mandiri dapat dilihat dari penjelasan di bawah ini.

Setelah ditetapkan judul penelitian oleh prodi dalam bentuk surat tugas pada akhir Februari, pembimbing melakukan pertemuan dengan mahasiswa untuk membahas proses pembimbingan dan memantapkan judul yang telah ditentukan. Tahap pertama ini dalam rangka membangun konteks. Adapun pertemuan pertama ini dilakukan melalui zoom meeting dengan membahas panduan penulisan skripsi agar mahasiswa dalam menyusun proposal akan lebih terarah dan memiliki sistematika yang baik dalam menulis, menjelaskan sistematika penulisan proposal, dan penentuan judul proposal yang baik karena dari tujuh judul yang ditetapkan masih ada empat mahasiswa lagi yang judul skripsinya perlu direvisi.

Tahap berikutnya yang disebut pemodelan teks, yaitu setiap mahasiswa mereview minimal lima artikel jurnal lima tahun terakhir sesuai dengan judul yang telah mahasiswa ajukan, melaporkan hasil review artikel satu minggu dalam pengerjaaannya secara sinkronus, mengumpulkan tugasnya melalui google
Volume 3, Nomor 2, Juli 2021

ISSN 2655-3031 (P), 2655-7851 (O)

DOI: http://dx.doi.org/10.29300/disastra.v3i2.4507

drive dan e-learning, mempresentasikan hasil review artikelnya sehingga menguatkan judul yang akan ditulis. Selain itu, mahasiswa membaca berbagai proposal penelitian atau mengikuti seminar proposal terutama mahasiswa yang belum lengkap persyaratan seminar proposal agar mampu menentukan atau menjadikan contoh proposal yang baik dalam menulis proposal nantinya.

Tahap ketiga, yaitu pembuatan teks secara bersama-sama. Tahap ini dilakukan pada penulisan draf awal proposal. Setiap mahasiswa mempresentasikan proposalnya masing-masing secara utuh dan bergantian, sedangkan mahasiswa lainnya bertanya atau menanggapi terhadap proposal yang telah mereka tulis. Diskusi secara bersama-sama ini dilakukan sampai tiga kali pertemuan melalui zoom meeting dan google meet sampai kesemua mahasiswa selesai mempresentasikan draf proposalnya. Masukan dan saran dari mahasiswa lainnya dan dosen pembimbing untuk dijadikan sebagai perbaikan kesempurnaan proposal yang ditulisnya.

Tahap keempat, yaitu penulisan teks secara mandiri. Artinya mahasiswa sudah menulis proposal secara mandiri terhadap proposal yang telah ditulisnya dengan secara aktif melakukan pembimbingan dan diskusi melalui grup WhatsApp, e-learning, dan google drive. Tahap ini setiap mahasiswa memiliki kesempatan dua kali perbaikan proposal atau direvisi oleh dosen pembimbing sehingga layak untuk mengajukan seminar proposal. Tahap penulisan secara mandiri ini mahasiswa bisa melihat dan mempelajari proposal temannya yang ada di google drive agar apa yang ditulis atau kesalahan sebelumnya tidak terulang lagi. Tahap ini mahasiswa juga

Arono, Syahriman, Nadrah

Model E-Genre Based Learning dalam Pembimbingan Penulisan Proposal Skripsi

Mahasiswa Pendidikan Bahasa Indonesia FKIP Universitas Bengkulu 
merevisi tulisannya dengan mengecek plagiasi maksimal $20 \%$ melalui tautan https://my.plagramme.com/. Jika cek plagiasinya belum mencapai di bawah $20 \%$, mahasiswa melakukan revisi secara mandiri.

Secara bertahap penerapan model $e$ genre based learning telah mampu meningkatkan keterampilan menulis proposal mahasiswa melalui pembimbingan dalam jaringan baik sinkronus maupun asinkronus. Hal tersebut membuktikan bahwa model ini dengan pembimbingan yang intensif efektif meningkatkan penyelesaian proposal skripsi mahasiswa dari kedelapan mahsiswa dalam penerapan model ini sudah 6 orang yang seminar proposal sejak awal April, sedangkan dua orang lagi masih menunggu penjadwalan seminar proposal. Keefektifan dalam penerapan model ini mendukung penelitian yang telah dilakukan sebelumnya oleh Arono \& Arsyad (2019) bahwa pendampingan model genre dalam penulisan draf artikel jurnal penelitian bidang humaniora pada dosen efektif meningkatkan kemampuan dosen dalam menulis artikel. Begitu juga dengan Mahanani, et al., 2018; Khasanah, 2018; Dewantara, et al., 2019; Resmisari, 2020 dengan model genre based learning dapat meningkatkan keterampilan menulis deskripsi siswa. Adapun peningkatan penulisan proposal skripsi mahasiswa dapat dilihat dalam penjelasan tabel di bawah ini.
Tabel 1. Distribusi Move dalam Bagian Pendahuluan

\begin{tabular}{llccc}
\hline No. & \multicolumn{1}{c}{ Deskripsi } & R.1 & R.2 & R.3 \\
\hline $\mathbf{1}$ & Alasan topik & 3 & 5 & 8 \\
$\mathbf{2}$ & $\begin{array}{l}\text { Meninjau } \\
\text { penelitian }\end{array}$ & 4 & 5 & 8 \\
& $\begin{array}{l}\text { sebelumnya } \\
\mathbf{3}\end{array}$ & & & \\
$\mathbf{4}$ & Menyatakan gap & 3 & 5 & 8 \\
& Rumusan & 5 & 6 & 8 \\
$\mathbf{5}$ & masalah & & & \\
\hline & Tujuan penelitian & 5 & 6 & 8 \\
\hline & Persentase & $57 \%$ & $77 \%$ & $100 \%$ \\
\hline
\end{tabular}

Berdasarkan tabel 1 mengenai distribusi move bagian pendahuluan proposal skripsi di atas menunjukkan bahwa dalam penerapan model pembimbingan $e$ genre based learning mengalami peningkatan sebesar $20 \%$ dari revisi pertama ke revisi kedua, sedangkan revisi kedua ke revisi ketiga mengalami peningkatan $23 \%$. Revisi pertama dilakukan dengan tahapan diskusi secara bersama, sedangkan tahapan ketiga dan keempat dilakukan pada tahapan mandiri dengan proses pembimbingan dari dosen pembimbing.

Alasan topik pada bagian pendahuluan masih kurang maksimal ditulis. Hal itu ditulis masih dalam bentuk penjelasan, seperti Pembelajaran bahasa Indonesia pada hakikatnya adalah...(P5/1/1). Kalimat tersebut masih disajikan dalam bentuk pengertian belum ada alasan bukti dan contohnya. Hal itu juga terjadi pada kalimat berikut ini, Dalam pembelajaran bahasa, terdapat empat komponen keterampilan berbahasa, yaitu ...(P5/1/1). Seharusnya bagian pendahuluan ini dapat ditulis seperti kalimat ini.

Provinsi Bengkulu memutuskan menunda pembukaan sekolah tatap muka pada semester genap Tahun Ajaran 2020/2021. Mengingat lonjakan kasus Covid-19 yang masih

Arono, Syahriman, Nadrah

Model E-Genre Based Learning dalam Pembimbingan Penulisan Proposal Skripsi Mahasiswa Pendidikan Bahasa Indonesia FKIP Universitas Bengkulu 
terus terjadi. Keputusan itu terbit melalui Surat Edaran Gubernur Bengkulu Nomor: 420/825/Dikbud/2020 tanggal 30 Desember 2020 (P7/1/1)

Kalimat di atas sudah menjelaskan data dan fakta yang mengemukakan alasan dalam bentuk data pentingnya pembelajaran daring. Selain itu, penanda bahasa yang lain menunjukkan bahwa kalimat dapat menyajikan pentingnya suatu penelitian selain data dan fakta, juga adanya kata-kata penghubung, seperti karena, sebab, oleh karena itu, seperti, dan contohnya. Pada bagian penelitian sebelumnya, mahasiswa masih belum mencantumkan peninjauan penelitian sebelumnya dalam bentuk diskusi di bagian pendahuluan melainkan menuliskannya di bagian subbab tersendiri di bab 2. Padahal, peninjauan perlu didiskuiskan dalam bagian pendahuluan seperti pernyataan berikut ini.

Berdasarkan ketiga penelitian yang telah dipaparkan, terdapat persamaan media pembelajaran yang diterapkan dalam penelitian ini, yaitu media audiovisual. Namun, terdapat beberapa perbedaan yang akan dilakukan penulis dengan penelitian terdahulu. Pada penelitian ini, ...(P8/1/1)

Kalimat tersebut ditulis setelah dijabarkan beberapa penelitian relevan sebelumnya kemudian disentesiskan persamaan dan perbedaan dengan penelitian yang akan dilakukan. Adapun pernyataan gap atau permasalahan penelitian ditulis lebih pada hasil observasi terhadap pembelajaran yang telah dilakukan dan penyelesaian yang akan dilakukan dalam penelitian, seperti dalam kalimat di bawah ini.

Berangkat dari pengalaman Magang II di semester VII, penulis menemukan
Volume 3, Nomor 2, Juli 2021

ISSN 2655-3031 (P), 2655-7851 (O)

DOI: http://dx.doi.org/10.29300/disastra.v3i2.4507

satu masalah mengenai bahan ajar yang digunakan untuk mengajar oleh guru. Bahan ajar yang dapat digunakan dan disediakan dari sekolah, yaitu bahan ajar berupa buku paket. Karena kegiatan magang dilaksanakan pada masa pandemi Covid-19 dengan pembelajaran daring, bahan ajar secara daring/file tidak tersedia. $(P 1 / 1 / 1)$

Rumusan masalah dan tujuan penelitian dalam penulisan proposal secara langsung sangat bersinergi dan berhubungan langsung. Namun, masih ada mahasiswa menulis rumusan masalah tidak sesuai dengan tujuan, seperti Untuk mengetahui bagaimanakah pelaksanaan pembelajaran... (P5/1/1). Seharusnya dalam menulis tujuan penelitian tidak ada lagi kata tanya, melainkan lansgung pada tujuannya, yaitu untuk mengetahui pelaksanaan pembelajaran...Hal lainya yang sudah benar, seperti pada tujuan penelitian kalimat berikut ini.

Tujuan penelitian ini untuk mengetahui:

1. Penerapan pembelajaran
menulis puisi
menggunakan
pembelajaran CIRC...

2. Kemampuan menulis puisi dengan menggunakan model pembelajaran CIRC...(P3/1/1)

Berdasarkan temuan bagian pedahuluan di atas menunjukkan bahwa komponen yag jarang mendapat perhatian bagi mahasiswa dalam menulis bagian bendahuluan, yaitu alasan topik sentral, meninjau penelitian sebelumnya, dan menyatakan gap. Pendahuluan lebih pada penulisan eskposisi atau memaparkan pengertian dan penjelasan saja pada awalnya, namun setelah dilakukan pembimbingan model e-genre based

Arono, Syahriman, Nadrah

Model E-Genre Based Learning dalam Pembimbingan Penulisan Proposal Skripsi

Mahasiswa Pendidikan Bahasa Indonesia FKIP Universitas Bengkulu 
learning sampai pada revisi kedua dan ketiga penulisannya menjadi lebih baik. Hal itu sesuai dengan yang dikemukakan oleh Arono \& Arsyad (2019) dalam penuliasn bagian pendahuluan yang menjadi permalasalahn dalam menulis bagian pendahuluan, yaitu alasan topik sentral, meninjau penelitian sebelumnya, dan menyatakan gap. Padahal bagian pendahuluan harus memuat menentukan alasan topik sentral, meninjau penelitian sebelumnya, menyatakan gap, menentukan rumusan masalah penelitian, dan menentukan tujuan penelitian. (Swales, 1990 \& 2004; Lim's, 2006; Arsyad \& Arono, 2016 \& 2019).

Tabel 2. Distribusi Move dalam Kajian Teori

\begin{tabular}{llccc}
\hline No. & Deskripsi & R.1 & R.2 & R.3 \\
\hline $\mathbf{1}$ & Ulasan sesuai & 3 & 5 & 8 \\
& topik & & & \\
$\mathbf{2}$ & Integral & 4 & 6 & 8 \\
$\mathbf{3}$ & Nonintegral & 3 & 5 & 8 \\
\hline & Persentase & $48 \%$ & $76 \%$ & $100 \%$ \\
\hline
\end{tabular}

Sebagai sintesis dari sumber bacaan penulis berdasarkan topik permasalahan penelitian dalam sebuah kajian teori bahwa dalam tulisan proposal yang ditulis mahasiswa sudah mengalami peningkatan pada tahap penulisan teks secara bersamasama dan mandiri, yaitu pada tahap revisi satu ke revisi kedua mencapai 28\%, sedangkang pada revisi kedua ke revisi ketiga peningkatannya mencapai $24 \%$. Ulasan sesuai topik pada revisi pertama kurang terlihat karena penulis hanya mendata teori-torinya saja belum mendiskusikan teori yang digunakan dalam penelitiannya, seperti pada kalimat berikut ini.

Bahan ajar merupakan salah satu aspek penting dalam dunia pendidikan. ...Widodo \& Jasmadi (dalam Lestari,
2013, hal. 1) menjelaskan bahwa bahan ajar adalah seperangkat sarana atau alat pembelajaran yang berisikan materi pembelajaran ... dalam (Ika Novita, 2020, hal. 47). (P1/2/2)

Kutipan teori di atas menjelaskan pengertian bahan ajar, tetapi sampai pada paragraf ketiga tidak disentesiskan maksud dari pengertian bahan ajar. Teori hanya didata dan dijelaskan saja padahal teori harus diduskusikan dan disentesiskan sesuai dengan permasalahan penelitian yang kita tulis, seperti pada kutipan kalimat di bawah ini

Berdasarkan uraian di atas dapat disimpulkan bahwa persepsi ialah proses dalam menggunakan sesuatu yang diterima melalui indra agar setiap orang bisa memilah, mengendalikan serta menerjemahkan sesuatu informasi untuk menghasilkan cerminan yang berarti. (P7/2/2)

Kajian pustaka dalam proposal penelitian bisa dilakukan secara integral dan nonintegral dengan tipe naratif. Tipe naratif ini penulis hanya mengkritik dan merangkum kumpuan literatur dan menarik kesimpulan tentang topik yang dibahas. Pengutipan model integral, yaitu nama penulis yang dikutip diletakkan pada awal kalimat kutipan kecuali dalam kalimat pasif nama penulis dijadikan sebagai pelaku, seperti pada contoh kalimat berikut ini.

Semi (2007:14) mengatakan bahwa menulis adalah suatu rangkaian tindakan dalam bentuk kreatifitas ...Selanjutnya Dalman (2016:4) juga mengemukakan bahwa, menulis merupakan suatu kegiatan komunikasi...Romadhon (2019:2) juga mengemukakan bahwa keterampilan menulis merupakan hasil produk inteligensi bahasa...(P4/2/1)

Pengutipan model nonintegral, yaitu nama penulis yang dikutip diletakkan pada

Arono, Syahriman, Nadrah

Model E-Genre Based Learning dalam Pembimbingan Penulisan Proposal Skripsi Mahasiswa Pendidikan Bahasa Indonesia FKIP Universitas Bengkulu 
akhir kalimat kutipan atau dalam bentuk angka yang merujuk kepada catatan kaki atau catatan akhir. Umumnya kutipan ini masih jarang digunakan oleh mahasiswa, namun setelah dijelaskan agar lebih bervariasi dan mendalam kutipan sebuah tulisan mahasiswa akhirnya dapat menuliskannya, seperti pada kutipan kalimat di bawah ini.

... serta memberikan penilaian dan rekomendasi (Rosset, 1992. ... informasi yang digunakan sebagai dasar dalam pengembangan bahan ajar (Brown, 2017). Analisis kebutuhan bahan ajar berperan untuk mempersiapkan tujuan. (P2/2/1)

Adapun kata kerja yang ditulis dalam menulis kutipan baik secara integral maupun nonintegral, yaitu mengemuakakan, mengatakan, menyatakan, mendiskusikan, menunjukkan, mengembangkan, mengidentifikasikan, menyampaikan, menyarankan, menilai, membuat, menganalisis, dan memikirkan. Kata kerja itu bisa digunakan dalam menulis kutipan dari setiap pendapat ahli yang kita rujuk atau kita acu baik secara kutipan langsung maupun kutipan tidak langsung.

Berdasarkan temuan bagian kajian pustaka di atas menunjukkan bahwa tipe kajian pustaka yang disajikan memiliki tipe naratif. Tipe naratif ini maksudnya penulis mengkritik dan merangkum kumpulan literatur dan menarik kesimpulan tentang topik yang dibahas. Hal ini sesuai yang dikemukakan oleh Cronin et al. (2008) dan Freak dan Swales (2009) bahwa tipe ini biasanya ditemui dalam penulisan tesis atau skripsi. Adapun cara pengutipan yang digunakan lebih dominan pada kutipan integral dibanding dengan nonintegral. Hal ini sesuai yang dikemukakan oleh Swales (2009) bahwa kutipan nonintegral dibutuhkan kajian yang mendalam dalam sebuah kutipan dari beberapa pendapat ahli atau pakar yang disajikan dalam argumentatif dan persuatif (Loan dan Pramoolsoop, 2016).

Tabel 3. Distribusi Move dalam Metodologi Penelitian

\begin{tabular}{llccc}
\hline No. & \multicolumn{1}{c}{ Deskripsi } & R.1 & R.2 & R.3 \\
\hline $\mathbf{1}$ & Alasan \\
menggunakan & 3 & 5 & 8 \\
$\mathbf{2}$ & $\begin{array}{l}\text { metode } \\
\text { Teknik } \\
\text { pengumpulan } \\
\text { data }\end{array}$ & 4 & 5 & 8 \\
$\mathbf{3}$ & $\begin{array}{l}\text { Teknik analisis } \\
\text { data }\end{array}$ & 5 & 6 & 8 \\
$\mathbf{4}$ & Keabsahan data & 3 & 6 & 8 \\
\hline & Persentase & $54 \%$ & $79 \%$ & $100 \%$ \\
\hline & Berdasarkan & tabel & di & atas
\end{tabular}

menujukkan bahwa dalam setiap tahapan pembimbingan baik secara bersama-sama maupun secara mandiri mengalami peningkatan. Peningkatan tersebut terlihat dari revisi pertama ke revisi kedua mencapai $25 \%$, sedangkan dari revisi kedua ke revisi ketiga peningkatan mencapai $21 \%$. Secara umum bahwa proposal yang ditulis oleh mahasiswa sudah terdapat setiap move yang ada di bagian metodologi penelitian, tetapi masih ada kurang penjelasan terhadap setiap move yang disampaikan. Kurangnya penjelasan alasan memilih metode penelitian terlihat pda kutipan kalimat di bawah ini.

Penelitian ini menggunakan metode kuantitatif. Metode kuantitatif adalah suatu proses yang menemukan dlam bidang pengetahuan dengan menggunakan data berupa angkaangka sebagai alat keterangan apa yang ingin di temui atau diketahui. $(\mathrm{P} 6 / 3 / 1)$

Alasan menggunakan metode labih diperlukan dalam bab 3 bagian metodologi

Arono, Syahriman, Nadrah

Model E-Genre Based Learning dalam Pembimbingan Penulisan Proposal Skripsi Mahasiswa Pendidikan Bahasa Indonesia FKIP Universitas Bengkulu 
penelitian ini bukan hanya sekadar mendata metode yang digunakan saja. Hal itu dapat kita lihat dari kutipan kalimat beikut ini.

Alasan penggunaan metode ini untuk memberikan pemahaman terhadap masalah penelitian yang lebih baik daripada menggunakan pendekatan tunggal. Pada penelitian ini digunakan proses penelitian secara exploratory research desigh pada hasil penelitian terdapat kesimpulan secara kualitatif (naratif), dibuktikan dengan angka-angka, sehingga jadi logis, akurat dan dapat di prosentasikan. (P3/3/2)

Di antara bagian teknik pengumpulan data, analisis data, dan keabsahan data, bagian keabsahan data masih kurang terlihat penjelasannya dibadingkan bagian lainnya. Mahasiswa menganggap bahwa teknik analisis data sudah mewakili penjelasan pada bagian keabsahan data. Padahal keabsahan data merupakan kelanjutan dari analisis data sehingga data penelitian yang digunakan atau yang dianalisis akan lebih valid dan relieabel. Hal itu dapat kita lihat dari kutipan kalimat di bawah ini.

Untuk mengecek keabsahan data, penulis menggunakan triangulasi yang dikemukakan oleh Wiersma (1986). Triangulasi bertujuan untuk menguji kredibilitas data dilakukan dengan cara mengecek data kepada sumber yang sama dengan teknik yang berbeda. (P7/3/4)

Bagian metodologi penelitian pada bab 3 ini lebih pada mendata metode dan tahapan apa yang akan digunakan dalam penelitian dengan sejumlah alasan-alasan penting agar penelitian yang akan dilakukan dapat dilaksanakan dengan baik. Dalam menjelasakan data-data setiap tahapan perlu ditambah alasan bukti dan contoh serta teori yang dugunakan agar meyakinkan kita
Volume 3, Nomor 2, Juli 2021

ISSN 2655-3031 (P), 2655-7851 (O)

DOI: http://dx.doi.org/10.29300/disastra.v3i2.4507

sebagai penulis dalam melakukan penelitian. Hal itu sesuai yang dikemukakan oleh Swales (1990 \& 2004), Lim's (2006), dan Arsyad \& Arono (2016), dan Arono \& Arsyad (2019 \& 2020) bahwa bagian metodologi penelitian dituliskan mengenai alasan menggunakan metode, teknik pengumpulan data, teknik analisis data, dan keabsahan data.

Berdasarkan hasil respon mahasiswa setelah melakukan penerapan model genre based learning secara daring menunjukkan bahwa mahasiswa memiliki respon positif. Ada beberapa dampak positif dari penerapan model ini secara daring, yaitu mempercepat proses pembimbingan, hemat secara waktu dan biaya, dapat lebih mudah mengakses sumber dan bahan internet secara langsung, mahasiswa dapat berinteraksi dengan pembimbing maupun antarmahasiswa dengan cepat dan baik, mampu merefleksi diri dengan cepat terhadap berbagai revisi dan kesalahan penulisan, dan lebih percaya diri dalam perbaikan dan revisi tulisan proposalnya. Seperti yang dikemukakan Irawati \& Santaria (2020) dan Nusantari et al. (2020) dalam pembelajaran daring perlu didukung oleh sumber belajar, strategi pembelajaran, learning support, dan administrasi.

Adapun kekurangannya dalam penerapan model genre based learning dengan pembimbingan ini masih ada mahasiswa yang mengalami kendala dalam mengakses aplikasi dalam proses pembimbingan karena mahasiswa terbiasa menggunakan gawai. Artinya di sini mahasiswa kurang terlatih memanfaatkan teknologi, seperti yang dikemukakan Mulyono et al. (2021) bahwa yang menjadi kendala dalam pembelajaran daring karena masih kurangnya terlatih baik dari segi guru

Arono, Syahriman, Nadrah

Model E-Genre Based Learning dalam Pembimbingan Penulisan Proposal Skripsi

Mahasiswa Pendidikan Bahasa Indonesia FKIP Universitas Bengkulu 
dan siswa dalam memanfaatkan teknologi. Hal itu menyebabkan beberapa proses pembimbingan tidak bisa diikuti dengan baik karena perbaikan dalam merevisi atau mengedit proposal tidak bisa dilakukan dengan baik melalui gawai. Berbagai kesulitan yang dihadapi dalam pembbimbingan yang dikemukakan oleh Siswanto \& Sampurno (2015) tidak ditemui dalam penerapan model ini karena dilakukan secara daring.

\section{Simpulan}

Model e-genre based learning dalam pembimbingan proposal skripsi mampu meningkatkan kualitas proposal menulis mahasiswa dalam penyelesaian proposalnya. Hal tersebut dapat dilihat dari tahapan yang dilakukan dalam penerapan model ini baik pada tahap pembangunan konteks, pemodelan teks, pembuatan teks secara bersama-sama, maupun tahap pembuatan teks secara mandiri. Hal yang paling dominan terjadi peningkatan dalam menulis proposal mahasiswa ini, yaitu tahap pembuatan teks secara mandiri dan secara bersama-sama, tetapi tahap pembangun konteks dan pemodelan teks sangat menentukan keberhasilan mahasiswa dalam menulis proposal pada tahap pengembangan model berikutnya baik secara sinkronus maupun asinkronus. Peningkatan penulisan proposal penelitian skripsi mahasiswa dengan model e-genre based learning baik pada bagian pendahuluan, kajian pustaka, maupun metode penelitian secara keseluruhan rata-rata meningkat sebesar 24\%. Peningkatan itu dapat dikategorikan baik $(77 \%)$ dengan melihat rata-rata persentase awal ditambah dengan rata-rata setiap revisi dalam penyelesai proposal yang dilakukan oleh mahasiswa.
Volume 3, Nomor 2, Juli 2021

ISSN 2655-3031 (P), 2655-7851 (O)

DOI: http://dx.doi.org/10.29300/disastra.v3i2.4507

\section{Daftar Pustaka}

Arikunto, S. 1980. Prosedur Penelitian: Suatu Pendekatan Praktik. Jakarta: Rineka.

Arono, A. \& Arsyad, S. (2019). The Effect of Genre-Based Mentoring on Rhetorical Quality of Research Article Drafts by Indonesian Lecturers in Social Sciences and Humanities. International Journal of Instruction, 12(3), 35-50. https://doi.org/10.29333/iji.2019.1233 a

Arono, A. \& Arsyad, S. (2020). Pelatihan Penulisan Karya Tulis Ilmiah Bagian Abstrak dan Pendahuluan Model Induktif Partisipatif pada Guru SMA/SMK/MA dan Dosen Bahasa di Lubuk Linggau dalam Peningkatan Profesionalitas. Dedication: Jurnal Pengabdian Masyarakat. 4 (2), 25488813.

https://doi.org/10.31537/dedication.v4 i2.365.

Arsyad, S. \& Arono. (2016). Sukses Menulis Pendahuluan Artikel Jurnal Internasional. Jakarta: Halaman Moeka.

Arsyad, S. \& Arono. (2019). Menulis Telaah Pustaka untuk Artikel Jurnal Internasional. Jakarta: Halaman Moeka.

Bawarshi, A., \& Reiff, M. J. (2010). Genre: An introduction to history, theory, research, and pedagogy. West Lafayette, IN: Parlor Press.

Bhatia, V. K. (1993). Analysing Genre: Language Use in Professional Settings. Burnt Mill, England: Longman.

Burgos, E. G. (2017). Use of the genrebased approach to teach expository 
essays to English pedagogy students. HOW, 24(2), 141-159. http://dx.doi.org/10.19183/how.24.2.3 30

Creswell, J.W. (2008). Educational Research: Planning, Conducting, and Evaluating Quantitative and Qualitative Research. New Jersey: Pearson Merril Prentice Hall.

Cronin, P., Ryan, F., \& Coughlan, M. (2008). Udertaking a Literature Review: A step Approach. British Journal of Nursing. 17(1), 38-43.

Dewantara, A. B. J., Sutama, I. M., \& Wisudariani, N. M. R. (2019). Pembelajaran bahasa Indonesia berbasis teks di SMA Negeri 1 Singaraja. Jurnal Pendidikan Bahasa dan Sastra Indonesia Undiksha, 9(2).

Feez, S. \& Joyce, H. (2002). Text-based syllabus design. Sydney, NSW : Ames.

Freak, C. B. \& Swales, J. M. (2009). Telling a Research Antory: Writing a Literature Review. Michigan: The University of Michigan Press.

Hariyati, R. M. (2012). Survey kinerja dosen pembimbing skripsi dan kualitas skripsi mahasiswa akuntansi stie malangkucecwara. Jurnal Dinamika Akuntansi, 4(2).

Irawati, R., \& Santaria, R. (2020). Persepsi Siswa SMAN 1 Palopo Terhadap Pelaksanaan Pembelajaran Daring Mata Pelajaran Kimia. Jurnal Studi Guru Dan Pembelajaran,3(2), 264270.

Iswari, M., Kasiyati, K., Zulmiyetri, Z., \& Ardisal, A. (2017). Bimbingan Teknis Penyusunan Proposal Penelitian Tindakan Kelas dan Penulisan Artikel pada Guru-Guru Sekolah dasar di SD
Volume 3, Nomor 2, Juli 2021

ISSN 2655-3031 (P), 2655-7851 (O)

DOI: http://dx.doi.org/10.29300/disastra.v3i2.4507

N 17 Limau Manis Padang. Jurnal Konseling dan Pendidikan, 5(3), 156162.

Iswanto, I., \& Hidayat, D. (2020). Perubahan Budaya Tatap Muka Menjadi Online dalam Bimbingan Skripsi Mahasiswa. LUGAS Jurnal Komunikasi, 4(2), 78-85.

Khasanah, M. (2018). Peningkatan Keterampilan Menulis Descriptive Text melalui Genre Based Approach Berbantuan Media Instagram. Paedagogie, 13(1), 9-18.

Kurniawan, H., \& Bondowoso, W. B. (2020). Sistem Informasi Terintegrasi Tugas Akhir/Skripsi Berbasis Web (Studi Kasus: Jurusan Sistem Informasi Institut Informatika dan Bisnis Darmajaya). SIMADA (Jurnal Sistem Informasi dan Manajemen Basis Data), 2(2), 124-134.

Lim, J.M.H. (2006). Method sections of management research articles: A pedagogically motivated qualitative study. English for Specific Purposes, 25(3): 282-309.

Loan, N. T. T., \& Pramoolsoop, I. (2016). Citation Practice in The Whole TESOL Master's Theses by Vitnamese Postgraduates'. 3L: The Southeast Asian Journal of English Language Studies. 2(2), 1-17.

Mahanani, N., Mastuti, H., \& KA, A. P. (2018). Meningkatkan keterampilan menulis teks deskriptif melalui Genre Based Approach pada siswa kelas X MIPA 4 di SMA Negeri 5 Semarang tahun pelajaran 2018/2019. Media Penelitian Pendidikan: Jurnal Penelitian dalam Bidang Pendidikan dan Pengajaran, 12(1), 39-46. 


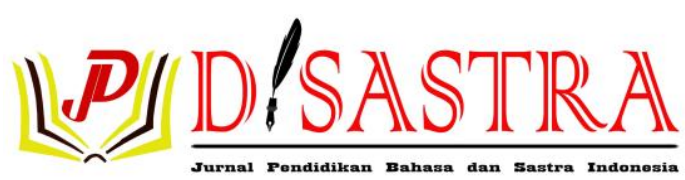

McMillan. 2008. Educational Research: Fundamental for the Consumer. New York: Pearson Merril Prentice Hall.

Mulyono, H., Ismayama, D., Liestyana, A. R., \& Komara, C. (2021). EFL Teachers' Peceptions of Indonesian Blended Learning Course Across Gender and Teaching Levels. Teaching English with Technology, 21(1), 60-74.

Nursalim, N. (2018). Peningkatan Kemampuan Guru Menyusun Proposal Penelitian Tindakan Kelas melalui Pembimbingan pada Sekolah Binaan. Ilmu Pendidikan: Jurnal Kajian Teori dan Praktik Kependidikan, 3(2), 131-138.

Nusantari, S. S., Sumarwati, S., \& Anindyarini, A. Pembelajaran Bahasa Indonesia Secara Online pada Masa Pandemi Covid-19 di SMA Islam Terpadu Nur Hidayah Sukoharjo. Basastra: Jurnal Bahasa, Sastra, dan Pengajarannya, 8(2), 206214.

Resmisari, N. L. (2020). Penerapan Genre Based Intruction Untuk Meningkatkan Keterampilan Menulis Siswa dalam Pokok Bahasan Application Letters. simpuljuara, 2(3), 193-198.

Rose, D., \& Martin, J. R. (2012). Learning to write, reading to learn: Genre, knowledge and pedagogy in the Sydney School. London: Equinox.

Swales, J. M. (1990). Genre Analysis: English in Academic and Research Settings, Cambridge, England: Cambridge University Press.

Swales, J. M. (2004). Research genres: Explorations and applications. Cambridge, England: Cambridge University Press.
Volume 3, Nomor 2, Juli 2021 ISSN 2655-3031 (P), 2655-7851 (O)

DOI: http://dx.doi.org/10.29300/disastra.v3i2.4507

Siswanto, I., \& Sampurno, Y. G. (2015). Faktor-Faktor Penghambat Pengerjaan Tugas Akhir Skripsi Mahasiswa Pendidikan Teknik Otomotif Ft Uny. Jurnal Taman Vokasi, 3(1).

Syaharuddin, S. (2020). Pembelajaran Masa Pandemi: Dari Konvensional Ke Daring. Pembelajaran Masa Pandemi: Dari Konvensional Ke Daring.

Widagdo, A., Abidin, A. Z., Ansori, I., \& Murtiningsih, T. (2010). Pemberdayaan Guru-guru SD melalui Pembimbingan Penulisan Proposal Pips (Ptk). Jurnal Abdimas, 14(2).

Yuliati, Y., \& Saputra, D. S. (2020). Membangun kemandirian belajar mahasiswa melalui Blended Learning di masa pandemi covid-19. Jurnal Elementaria Edukasia, 3(1). 